\title{
Recovering visual contacts in the historic cityscape
}

\section{Frolova Yuliia}

\author{
Department of architecture fundamentals and design of architectural environment, \\ Odessa State Academy of Civil Engineering and Architecture, e-mail: frolova@protonmail.com
}

\begin{abstract}
This article focuses on describing the process of the establishment of emotional contact between an observer and an urban identity in small historic areas. The objective is to formulate the terminological tools for describing phenomena of visual observation and spatial exploration by the observer. The author sets out tasks for future research
\end{abstract}

Keywords: historic areas, emotional and visual contacts, viewpoint, exterior and interior of the historic city.

\section{Introduction}

At a time when unregulated development of small historic towns and flawed methods of architectural preservation threaten to drastically alter the image of the city, protecting integrity in historic areas becomes a pressing issue. Past experience provides new methodological approaches for the comprehensive study and protection of the historic urban landscapes. According to the «Recommendation on the Historic Urban Landscape» published in 2011[1], the „historic urban landscape" is characterised by a complex system of factors which cover and shape all aspects of the development of human settlements. Following the definition above, a greater emphasis must be placed on perception and visual relationships in the historic areas.

In Ukraine, the legal foundation for the study of historic areas is set by laws and regional regulations $[2,3]$. The basis of these documents is a series of fundamental works by Ukrainian researchers (Y.Vodzynsky, V.Vechersky, L.Prybega), dedicated to the study of spatial and architectural, artistic and aesthetic features, anthropomorphic factors of urban development, preservation and regeneration of historic urban areas

The visual perception of cityscapes was explored in depth by Ukrainian, Polish and Lithuanian researchers. M.Purvinas and Y.Vodzynsky analyzed cityscape and described the graphic methodology of such analysis; G.Kopteva devoted her paper to the significance of urban picturesqueness and visual contacts between city landmarks and sights. The evaluation of city landscapes and the urban fabric was studied by J.Bogdanowski, M.Bevz, V.Vechersky, J.Wrana. These research papers have formed the background for future inquiry.

\section{Perception of an historic area}

During the process of forming and collecting impressions, the individual establishes a cognitive bridge between him/herself and the environment. Memorizing objects, events, feelings, and thoughts transforms individual observation into the valorization of the milieu; the person attaches significant emotional experiences to the elements of his/her environment [9]. This topic, widely contested, has been the subject of interdisciplinary investigation by psychology, sociology and architectural theory. Findings have emphasised the consistency and immutability of the process of impression formation by the viewer as well as the personalised nature of interaction with the environment, which serves as the starting point in contemporary urban design [7]. 
The emergence of visual contact between the viewer and the object of contemplation is a dynamic and continual process. The complete aesthetic disclosure of the city image cannot be achieved through simple photographing and aimless movement characteristic of mass tourist activity. Paintings, lithographs, photographs, and maps provide but an abstract idea of the aesthetic image of the city - a flat imprint of reality, which cannot fully express the features of the particular space and is stripped of the emotional impact, and duration in time and space. Physical presence, however, allows the observer to accumulate other important emotional and artistic features of the environment (season, time of day, lighting, weather etc.), forming a genuine emotional connection with the object of observation [10].

If the formation of impressions is dynamic and linked with temporal and spatial changes of visual images, the environment's aesthetic features must play a crucial role. Systematic gradual changes and rhythmic movement of viewpoints create a holistic idea of a place which could be characterized as dramatic. The quality and quantity of these viewpoint changes could also be compared with cinema. The camera directs our gaze, leading us through images to the main point of the film. The individual undergoes a similar direction when he/she wanders in in city, discovering new attractive and symbolic forms and buildings_or simply admiring the picturesqueness of cityscape as he/she walks. At this time, the establishment of an emotional dialogue between cityscape and observer begins based on judgements like "beauty-ugliness", "happy-depressive", "comfort-discomfort", "quiet-noisy", etc. These emotional aspects form an individual attitude to the cityscape and the city environment.

The direction is felt both in the enclosed space of the city (interior) and beyond its borders (exterior), when the observer is at great distance and perceives the limits of urban space.

\section{The exterior of historical city}

Contemplation of urban space from a distance creates a special impression and is capable of revealing the essence of the city's identity. Silhouettes of buildings, the correlation of the dominant and subdominant landmarks, and the outline of the cityscape's rhythmic changes, fore- and backgrounds picturesqueness - culminate artistic expression into one image. Travellers' diaries describe the city's panorama very accurately, attending to each of its parts with the purpose of forming a distinct image of a place and providing the reader with the "elements of "site reading" (Fig. 1, 2).

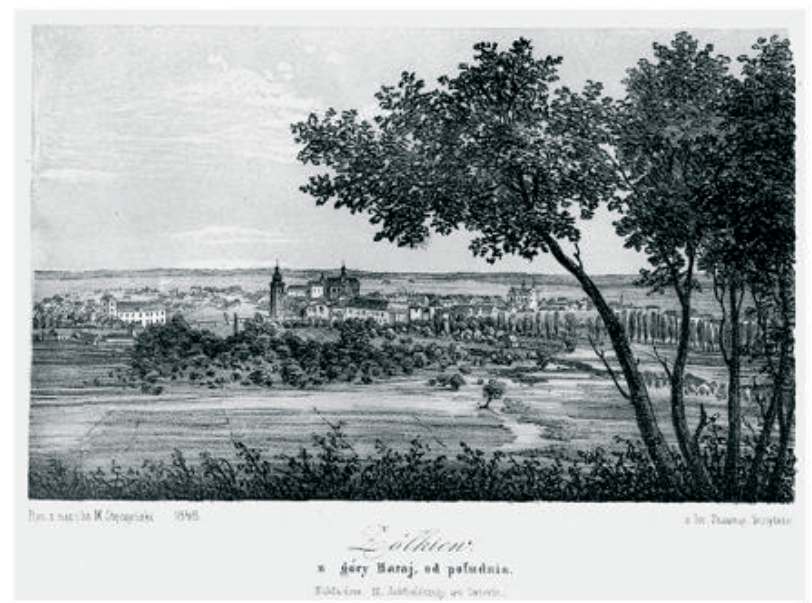

Fig. 1. Lithography of Zhovkva, Ukraine (1848) 


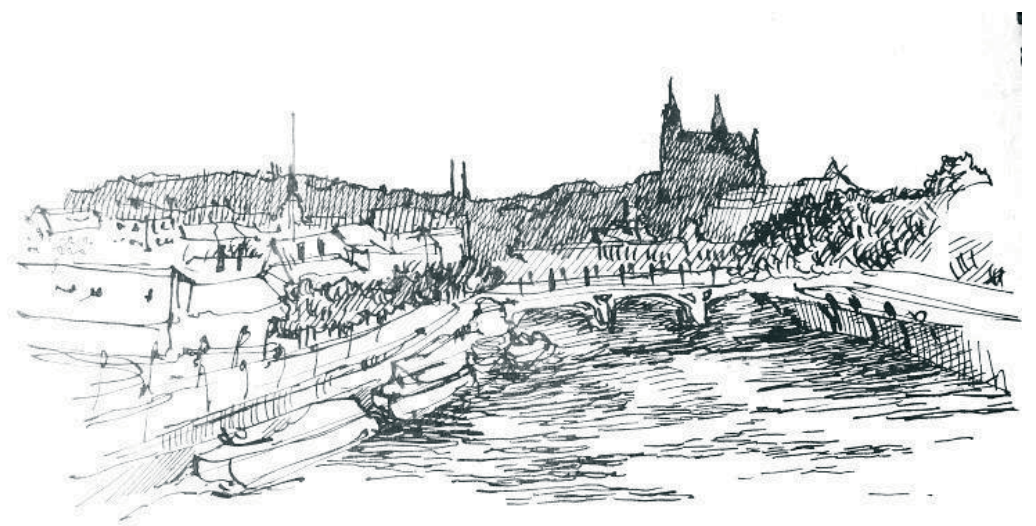

Fig. 2. Panorama of Prague, Czech Republic. Visual domination of Prague Castle (sketch by author)

Distance from the object of contemplation allows for a comparative analysis of natural environment and landscape character (proportion of greenery in the city, its dispersion in space, juxtaposition with the infinite horizon). To illustrate the significance of distance observation, the author produced drawings of a small historic city of Zhovkva (Ukraine). An analysis of its panorama shows that nearly all of the sacral buildings are dominating landmarks with minute differentiation of value among them (Figs. 3,4). If we turn to the history of the city, we discover that all religious parishes were given equal privileges. Another observation brought to light through topographic analysis is that those nearly all sacred buildings are situated on the ridge of the hill (Fig. 5).

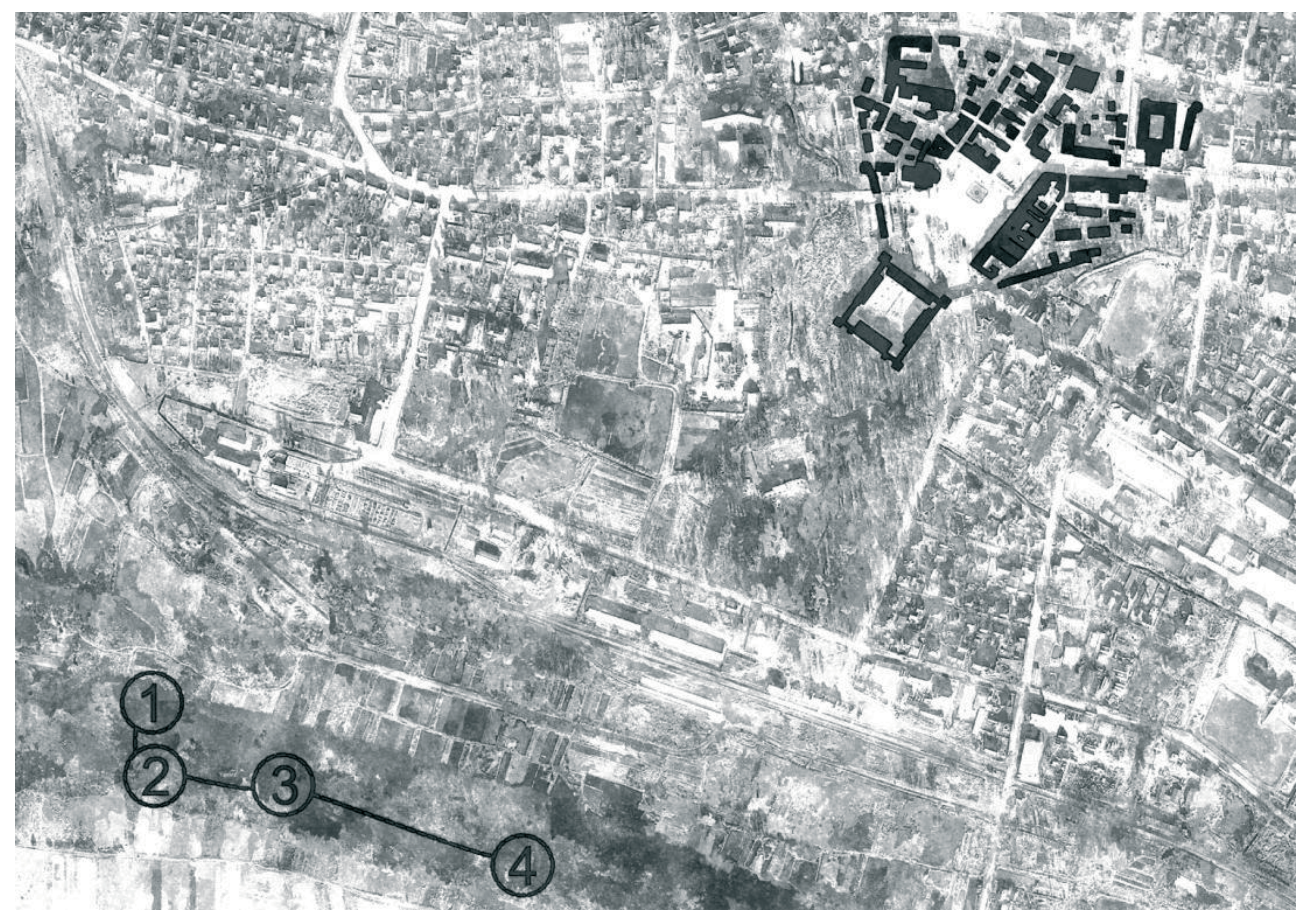

Fig. 3. Footprint of Zhovkva`s historic core and viewpoints 1-4 


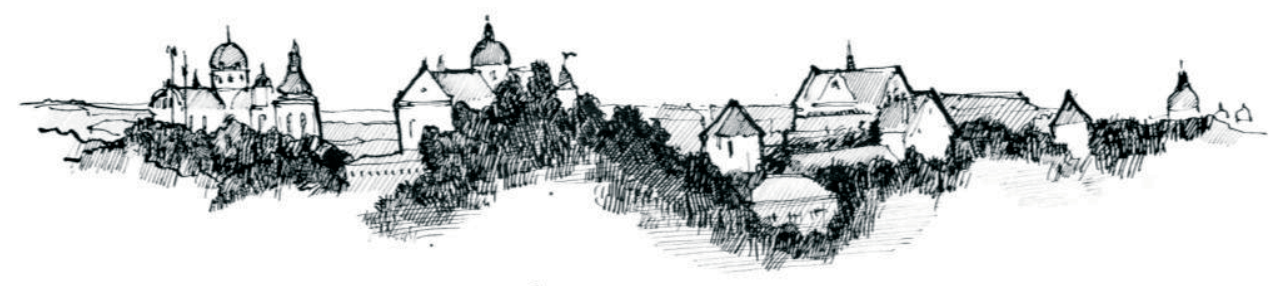

(a) Panorama of Zhovkva. Viewpoint 1.

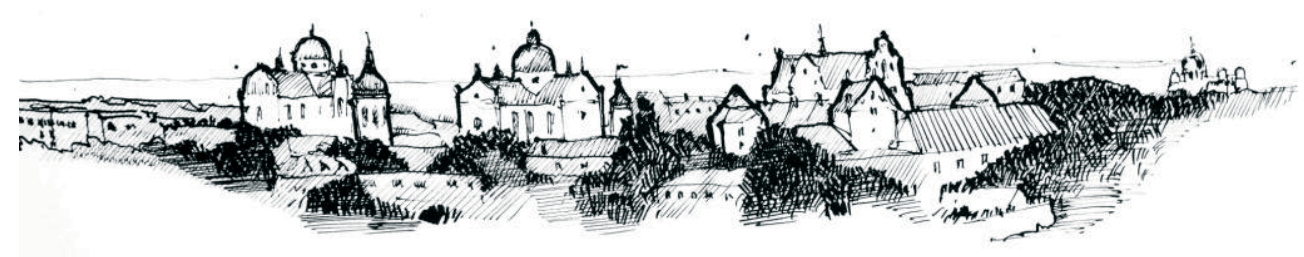

(b) Panorama of Zhovkva. Viewpoint 2.

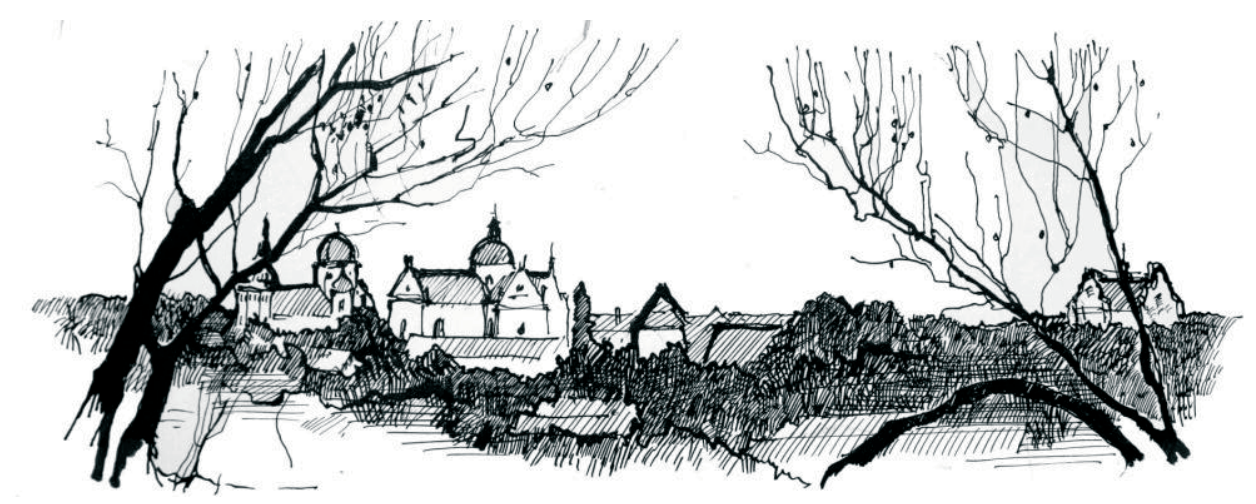

(c) Panorama of Zhovkva. Viewpoint 3.

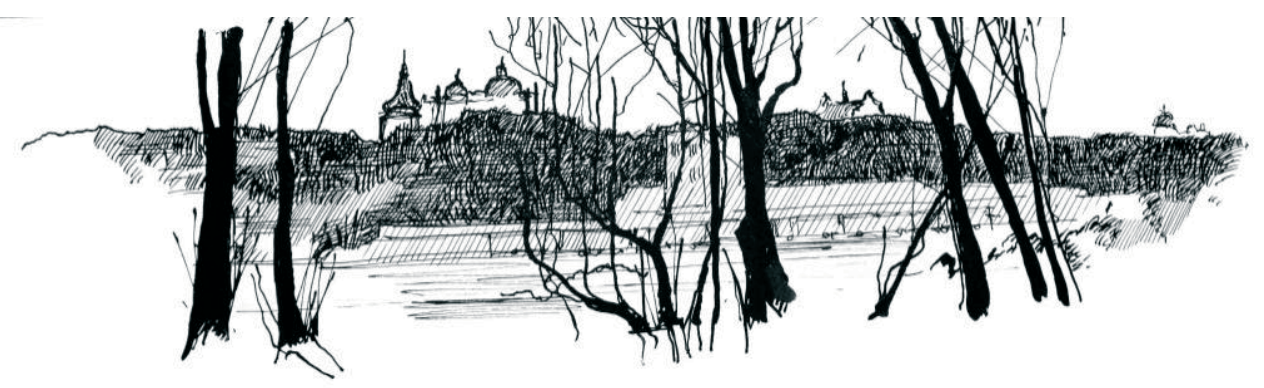

(d) Panorama of Zhovkva. Viewpoint 4.

Fig. 4. Disclosure of Zhovkva cityscape (sketches by author) 


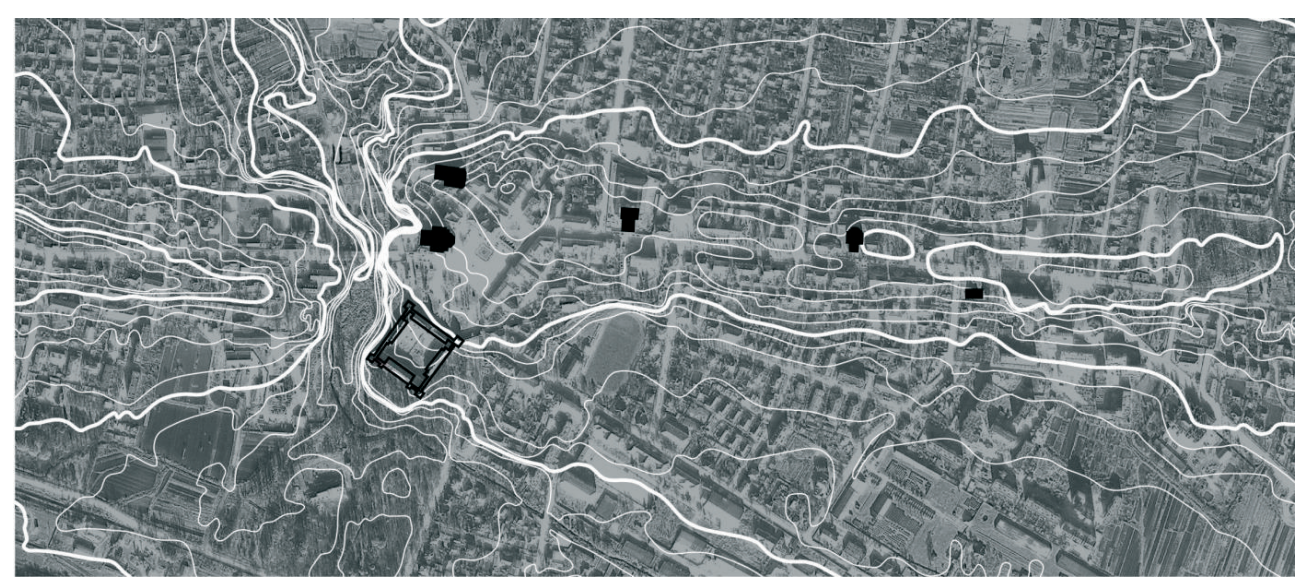

Fig. 5. Topographic map of Zhovkva with footprints of sacral buildings

The city's current urbanization irremediably affects historic cityscapes, changing their character and aesthetic value. Deprived of distinct visual domination and attraction, the historic cityscape is lost in dissonant rhythmic movement of spatial tags, evaluation of historic elements is levelled and replaced by background. Temporal changes in the Kyiv cityscape may serve as an example of the result of such a replacement of visual valuation (Fig. 6). Such an uncontrolled process could cause irreparable damage to small historic areas.

a)

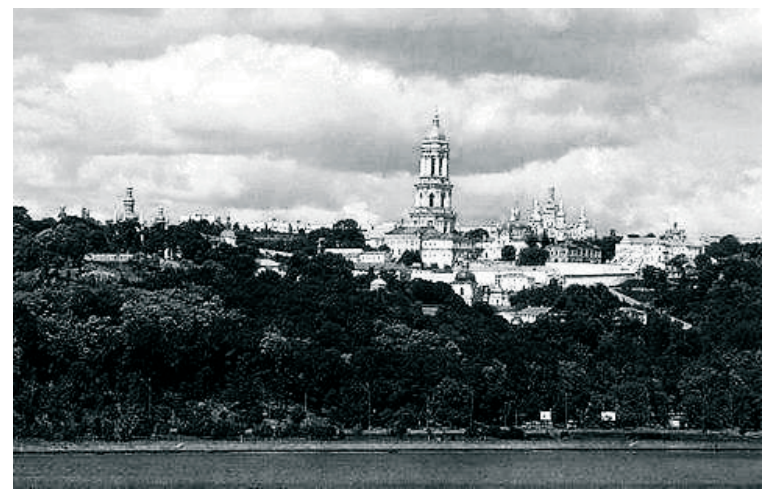

b)

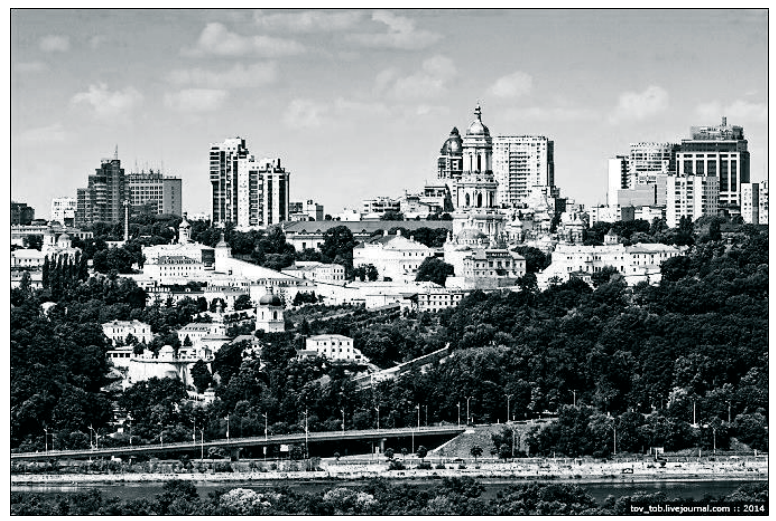

Fig. 6. Kiev cityscape . Change of city panorama: a) 1990th; b) 2014 (author Oleg Totski) 


\section{The interior of the historic city}

Interior observation of the historic city is also associated with the direction of space arising from the architectural and artistic aims; rhythmic and gradual changes of focal points, separation and framing of significant landmarks, the identification of specific reference points and axes. Inside the historic city, the observer limits his/her perception by the city scale, visual barriers (street facades) or "thresholds" (arches, bridges, doors etc.) [10], personal sensibility to the space, focusing on one of the many elements included in the urban structure organization. In this process, forming a holistic street space, restoring perspectival directions, and solving the issue of blind grey spot becomes of key importance.

An important consequence of an emotional connection with the internal urban environment is the process of personal city mental mapping. Relying on memory and habits, the route observer creates a number of interpretations of cityscapes, more distantly related to a real scale. A mental city map is a system of "emotional bridges", which form a personal spatial code notation and recognition [9].

Modern technologies of drone video monitoring allow one to contemplate the space of historic city on a much wider scale. A layperson, who lacks specific spatial imagination skills, is given the opportunity to see a panorama of the city in three dimensions: the street becomes disclosed, rooftops gain visibility, minute details in buildings are exposed to the observer who wouldn't notice them from the street, and the scale of the urban environment in relation to the person is truly experienced. The individual is able to model their own trajectory of gaze, focusing their eye on objects of contemplation of choice.

Modern technology also provides a substantial impulse towards the development of new more mobile methods of researching the historic urban environment. A combination of drones and photogrammetry stimulates a quicker and more efficient creation of threedimensional physical digital models that are vital for the analysis and research of the environment.

\section{Conclusion}

Person observes the historical cityscape on different visual and cognitive levels. The first level is the general perspective view of the cityscape or exterior, whereby all its elements create a holistic and picturesque image of the city, the rhythm of landmarks forms an unique silhouette, which could be read as the Oneness of an historical area. The city's opposition to the natural landscape provides an understanding of the scale and nature of the space. The second visual level is that of the city's interior, from this point the person explores an area in fragmented manner, he/she is unable to cover an entire historical area, and visually isolates and concentrates on particular elements of the cityscape (monument, landmark). The observer's "eye" is directed by focal points of the streets and avenues, by target viewpoints to the sights and architectural environment, which create stages and "thresholds" of urban picturesqueness.

Directing the observer's eye to the "target" point we are able to form a specific perception of the city. The picturesqueness of historic cityscapes could be recovered by analysis and contemporary urban design, which takes the architectural semantics of the city into account.

The author aims to analyse the existing methodologies of graphic and spatial analysis of cityscapes and to propose principles of study of small historic areas in further studies. 


\title{
References
}

1. Recommendation on the Historic Urban Landscape, including a glossary of definitions, UNESCO, 2011.

2. Law of Ukraine pro zahyst culturnoi spadschiny N 39, 2000.

3. DBN B.2.2-3-2012. Sklad ta zmist istoryko-architekturnogo opornogo planu naselenogo punktu.

4. Bevz M. Historical elements of design of the city environment at works on regeneration of reserved architectural complexes of the centers of cities. Journal Visnyk HDADM 9 (2005) 819.

5. Bogdanowski J. Kompozycja i planowanie w architekturze krajobrazu. Zakład Narodowy im . Ossolińskich, Wroclaw, 1976.

6. Bogdanowski J. Architektura krajobrazu. Państwowe Wydawictwo Naukowe, Warszawa Kraków, 1979.

7. Cullen G. The Concise Townscape. Elsevier, Oxford, 1971.

8. Dąbrowska-Budziło K. Wśród panoram Krakowa: o przemianach widoków $i$ o tym, jak je ocalić. Warszawa, 1990.

9. Januchta-Szostak A. The Role of Public Visual Art in Urban Space Recognition (ed. by Karl Perusich). Cognitive maps, 2010, 75-100.

10. Kopteva G. Semantyka "porogu"v architekturnij rytmike gorodskoj sredy (The semantics of "threshold" in the architectural rhythm of the city environment). Kharkov 2009.

11. Osychhenko G. Peyzazhniy pidhid do analizu estetichnih yakostey mistobudivnih ob'ektiv.( Landscape approach to the analysis of the aesthetic qualities of urban objects). Problemy teorii $\mathrm{i}$ istorii arhitektury Ukrainy 12 (2012) 122-127.

12. Prybega I. Pamiatkoznavstvo: pravova okhorona kulturnykh nadban. Zbirnyk dokumentiv (Monuments: the legal protection of cultural heritage. Collection of documents). Kyiv, 2009.

13. Purvinas M. On Visual Analysis of Town Space. Lietuvos TSR aukštujų mokyklų mokslo darbai, Miesto kompozicija ir funkcinis organizavimas, M. Šumausko sp., Vilnius, 1984. 52-62.

14. Vechersky V. The Old Urban Heritage: The Historical and Urbanistic Researches for Historic Preservation of Inhabited Sites in Ukraine. Kyiv, 2003.

15. Vodzynsky Y. Analysis of viewing uncovering of the monuments of architecture and its instruments. Ukrainian Academy of Arts 17 (2010) 154-161.

16. Wrana J. Rola i znaczenie architektury $w$ procesie scalania struktury przestrzennej miasta na przykladzie Lublina. Politechnika Lubelska, Lublin, 2014.

\section{Odtwarzanie historycznych panoram miasta}

\author{
Frolova Yuliia \\ Wydziat Architektury i Wzornictwa środowiska architektonicznego, \\ Odessa Akademia Budownictwa i Architektury.e-mail: frolova@protonmail.com
}

Streszczenie: ten artykuł opisuje proces formowania wzajemnych relacji oraz emocjonalnych kontaktów pomiędzy obserwatorem i identyfikacją miasta w jego niewielkich, historycznych obszarach. Głównym celem badań jest uformowanie właściwej terminologii opisującej zjawisko wizualnych powiązań oraz przestrzennej eksploracji widza. Praca jest wstępem do badań nad tym tematem w przyszłości.

Słowa kluczowe: obszary historyczne, emocjonalne oraz wizualne powiązania, punkty obserwacyjne, zewnętrze oraz wnętrze miast historycznych. 
